\title{
CRITICAL FACTORS IN THE ADOPTION OF OPEN SOURCE TECHNOLOGIES
}

\author{
Anidza Valentín-Rodríguez, University of Puerto Rico, anidza.valentin@upr.edu \\ Angel M. Ojeda-Castro, Universidad del Turabo,ut_aojeda@suagm.edu \\ Macedonio Alanís- González, Tecnológico de Monterrey, alanis@itesm.mx \\ Eulalia Márquez-Martínez, Universidad del Turabo,emarquez@suagm.edu \\ Aury M. Curbelo-Ruiz, University of Puerto Rico, aury.curbelo@upr.edu
}

\begin{abstract}
The main purpose of this study was to determine the factors that may influence the adoption of open source software (OSS) and compare its use between four institutions within a public university. Six variables were identified as independent factors and one variable as dependent factor. A survey was administered to 360 students and faculty members. The Mann-Whitney U statistical test, as well as the Spearman statistical test was used to support or disavow the hypothesis stated in this research. The results of the study show a significant influence in the following factors: compatibility with existing applications, the ability to test the software before implementation, the license that is distributed with the software, the availability of support for the software, the technical skills of the information systems personnel and cost, with the attitude towards the use of the open source technology. We found a significant influence between the students and the faculty members in such factors as: the compatibility of the existing applications, the ability to test the software before implementation, and the use of open source technologies in the workplace. We also found the existence of a significant difference in the costs of these open source technologies between institutions with lower and higher assigned budgets.
\end{abstract}

Keywords: Open Source Software (OSS), Open Source Technologies, Open Source Technology, Technology Adoption, Free Software, Proprietary Programs, Software License

\section{Background}

\section{INTRODUCTION}

Open source software (OSS) has become an important and influential practice as a fundamental platform in the field of informatics [3]. Informatics programs that are developed from open source technologies make it easier for the user to modify and redistribute copies freely [7]. Commercial users, in the expectation of legal risks that pertain to the use of OSS, expect superior programs with additional features and are willing to pay for these additional characters as compared to academic users [19].

A great number of businesses use OSS, such as: Linux, MySQL and Apache [21]. Public and private companies are using them because it offers several advantages as compared to proprietary programs [12]. The advantages are ranked as follows: freedom of use, the evolution of the software, costs, the quality of the software and the support provided by the knowledge of its use [12]. Also, many governments are using this type of technology to reduce costs [11], and its use has been increasing [22].

Numerous developing countries are adopting policies to make low budget technologies available for low-income populations. Unfortunately, some governments, such as China, South Korea and India, have pursued the adoption of these technologies and have not taken into consideration that the majority of the final users are not familiarized with OSS. A great number of these users do not trust its quality, stability or security [28]. European cities such as Munich and Vienna have partially switched to the use of open source software as a measure to control costs and to personalize applications to their financial realities and service needs [11].

\section{Open Source Software in Education}

In the field of education, research has been performed where open source technologies have been implemented to develop instructional content and delivery systems [31]. Universities, such as Carnegie Mellon, Oregon State 
University, Universidad Pedagógica Nacional at Mexico City and the University of Michigan are some of the academic institutions that have developed OSS to benefit the academic community [18]. It is estimated that $25 \%$ of all academic institutions of higher education participate actively in the implementation of specific open source applications of any kind [1]. Some members of the higher education community are considering the use these technologies as a main option to attend their academic needs [15].

Close to $66 \%$ of information systems directors are considering the adoption of open source software [1]. Due to this action, what is left is to estimate the level of user acceptance of this technology in institutions, which would explain [25] its proportionality with their popularity. Therefore, the general idea that these software should be of free distribution is important for educational institutions, for when a particular package is selected, the decision is implicitly made for the students as well [26].

There is an increasing use and development of open source technologies [32], including Learning Management Systems (LMS), such as Moodle and Sakai in colleges and universities in the United States [5]. These technologies are being considered as the key to building integrated learning environments that serve academic and commercial needs in the organization, within the limits of their technical resources and budgets reality [30]. Regrettably, many organizations consider the adoption of OSS, but they do not anticipate the risks [2].

\section{LITERATURE REVIEW}

\section{Technology Acceptance Model}

The Technology Acceptance Model (TAM) suggests that the perceived usefulness and perceived ease of use are the two main factors to explain the adoption of technologies in an individual's workplace [20]. This is based upon the principle adopted by the Theory of Reasonable Action (TRA) [13]. The way to measure a behavior, such as attitude, establishes how external stimuli; such as objective characters of an attitude, are directly related to the beliefs and the behaviors of the individual [9].

Information Systems Model shows how the users come to accept and use a given technology [24]. The model is considered a powerful and efficient tool to predict acceptance by information technology users [14]. The Technology Acceptance Model predicts technology acceptance on two variables: Perceived Usefulness and Perceived Ease of Use, both serving as basis to determine the attitude towards the use of the system and influenced by external factors $[8,9,16,20$, and 23$]$.

The Perceived Utility is the user's subjective probability that when using the application it will increase work performance [8]. Perceived Ease of Use explains the degree in which the user expects the system to be free of effort [8]. The Technology Acceptance Model sustain that the beliefs, such as Perceived Utility and Perceived Ease of Use are important in the prediction of behaviors by the users in terms of the acceptance of computerized systems [16]. These will determine the attitude for use, which in turn is the evaluation of the users in the convenience to apply and use a specific technology, while the usage behavior reflects the probability the user chooses a specific application [14].

\section{The Costs of Information Technologies}

In 2011, universities worldwide suffered a 33\% reduction in the budgets for information technologies main services, $41 \%$ in 2010 and $50 \%$ in 2009 [5]. Open source technologies may generate important savings to businesses besides greatly contributing towards important standards in the field of documentation in general [6]. An example is Kinki University Technical College, who adopted the use of open source technologies to reduce expenses and cut 2.5 times the original cost of licenses [29].

\section{Pros and Cons in the Use of Open Source Software}

Among the advantages, we have the liberty to use, the evolution of software, time, costs and effort, quality of the software and the advantages to the companies and their programmers. Among the disadvantages, we may find hidden costs, technical problems, and quality and security issues [28]. 
References [10] suggest several advantages offered to education with this type of programming, for example, free of cost programs to students and tools to learn about academic subjects that may not necessarily pertain to the field of informatics. Universities worldwide are paying more attention to these programs, which are becoming an interesting aspect in on-line learning and are competing with solutions provided by proprietary licenses [17].

The solutions obtained by OSS may become expensive as compared to the solutions developed commercially, once the costs of configuration, training and support are included [23]. Developers see as a disadvantage the need to hire programmers to supplement their personnel, which may increase the cost as compared to proprietary programs and are worried by the risks in security, limited support and short life span [31]. There are capacitation and support costs related to the adoption of this technology; there is great need for skilled personnel dedicated to the community and legal fees in the development of commercial strategies [2].

Most end users of OSS are not familiarized with such technology, from which a significant amount do not trust its quality, stability or security [28].

\section{OBJECTIVES OF THE STUDY}

The main objective of this study was to determine the critical factors that may exist in universities towards the use of open source software, compare differences for each one of these factors between students and faculty members and compare critical factors between institutions with higher and lower assigned budgets.

\section{QUESTIONS}

1. Which are the most used open source software by students and faculty members?

2. Which are the critical factors that differ in the adoption of open source software between students and faculty members?

3. Which are the critical factors that differ in the adoption of open source software between institutions with higher and lower budgets?

\section{HYPOTHESES}

The research hypotheses to be tested are as follows:

$\mathrm{H}_{1}$ : The compatibility with existing programs will have a significant effect in the adoption of open source software.

$\mathrm{H}_{2}$ : The ability to test the software before implementation will have a significant effect in the adoption of open source software.

$\mathrm{H}_{3}$ : The license that is distributed with the software will have a significant effect in the adoption of open source software.

$\mathrm{H}_{4}$ : The software's support availability will have a significant effect in the adoption of open source software.

$\mathrm{H}_{5}$ : The personnel's technical skills will have a significant effect in the adoption of open source software.

$\mathrm{H}_{6}$ : Costs will have a significant effect in the adoption of open source software.

\section{RESEARCH METHODOLOGY}

The research design was non-experimental with a quantitative focus. It included the collaboration of 360 students and faculty members active in four institutions of higher education. A 26-item questionnaire was used. The questions had answer options according to the Liker scale. To analyze the instrument the samples were subject to a Kaiser-Meyer Olkin (KMO) and a Bartlett adequacy test; a Shapiro-Wilk normality test to determine the appropriate statistical test and a Mann-Whitney $U$ test to support or disprove the questions stated by the researcher, and a Spearman statistical test to validate the hypotheses previously stipulated.

The independent variables used to answer the questions are external variables in the Technology Acceptance Model. The factors under consideration were adapted in the research [27] taking into account the six factors of higher impact for businesses and the least significant factor (costs). The technology adoption factors were measured through the independent variables: compatibility, to test the software before implementation, license, support 
availability, technical skill and cost; the dependent variable was measured through the attitude towards use of open source software.

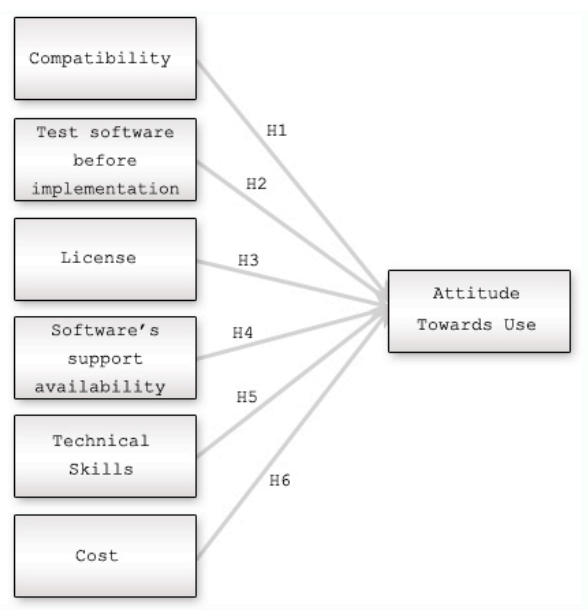

Figure 1. Research Model

\section{RESULTS}

The questionnaires were answered by the students $(80 \%, \mathrm{~N}=288)$, and faculty members $(20 \%, \mathrm{~N}=72)$, from a wide range of Departments. The dominant gender was female $(58 \%, \mathrm{~N}=210)$, being this an expected result considering the stratified sample already calculated at the beginning of this study. This data suggests that the college population is primarily composed of female students.

Two profiles were stipulated in this research; one for the students and the other for the faculty members. A great part of the participation came from the students between 17 and 22 years of age $(70 \%, \mathrm{~N}=202)$ officially registered in Institution $2(45 \%, \mathrm{~N}=129)$. In terms of academic level, the majority were undergraduates $(85 \%, \mathrm{~N}=246)$ in their sophomore year $(24 \%, \mathrm{~N}=70)$. Results point towards a major representation from Business Administration ( $11.8 \%$, $\mathrm{N}=34)$, and Biology $(11.5 \%, \mathrm{~N}=33)$. In terms of using the open source software, the students stipulated that their institutions do use these technologies $(86 \%, \mathrm{~N}=248)$.

The professors who agreed to participate were within the ages of 25 and 31 years $(29 \%, \mathrm{~N}=21)$ and between 46 and 52 years of age $(25 \%, \mathrm{~N}=18)$. Such as with the students, the highest participation came from Institution $2(60 \%$, $\mathrm{N}=43)$ where they offered undergraduate courses $(56.9 \%, \mathrm{~N}=41)$ in Business Administration $(26.4 \%, \mathrm{~N}=19$ and were Full professors $(47.2 \%, \mathrm{~N}=34)$. In terms of the use of open source software, the faculty members stipulated that they do use them $(85 \%, \mathrm{~N}=61)$.

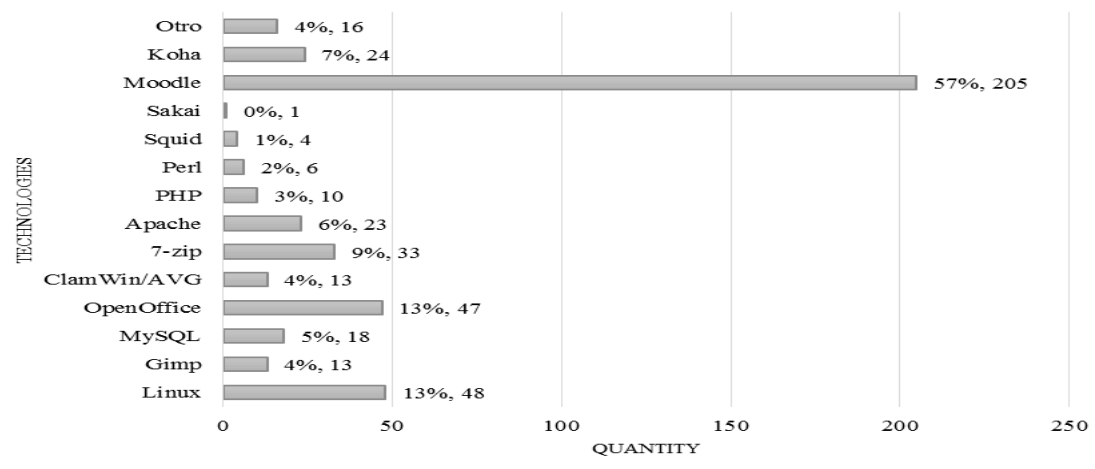

Figure 2. Open Source Technologies used by Students and Professors 
The OSS most used by the academic population were Mozilla Firefox $(73 \%, \mathrm{~N}=263)$, followed by the Course Management System Moodle (57\%, N=205), Open Office (13\%) and Linux (13\%). The participants indicated other open source technologies that were used in their institutions, but were not part of this questionnaire $(14 \%, \mathrm{~N}=16)$. These technologies were the Audacity Audio Editor, the Mandarin M3 Library automation, the Edu 2.0 Learning management on-line system, DropBox, Internet (VoIP) Skype voice system, the Wiki collaboration sites, the PDF Adobe Reader files and the Google Chrome and Internet Explorer navigators.

Table 1. Alpha Cronbach Reliability Test for the questionnaire

\begin{tabular}{ccc}
\hline $\begin{array}{c}\text { Cronbach's } \\
\text { Alpha }\end{array}$ & $\begin{array}{c}\text { Cronbach's Alpha Based on } \\
\text { Standardized Items }\end{array}$ & N of Items \\
\hline .899 & .902 & 17 \\
\hline
\end{tabular}

Table 2. Kaiser-Meyer-Olkin (KMO) and Batlett Sphericity tests

\begin{tabular}{llr}
\hline Kaiser-Meyer-Olkin Measure of Sampling Adequacy & .899 \\
Bartlett Test of Sphericity & Approx. Chi-Square & 3302.614 \\
& df & 136 \\
& Sig. & .000 \\
\hline
\end{tabular}

The result is supposed to be as close to one as possible, being 0.5 the minimum absolute value. A value over 0.8 is considered good. The KMO test gave a result of 0.899 , indicating that the sample was within adequacy. Besides the KMO test, we considered the Bartlett Sphericity test which was statistically significant $(<.05)$ with a result of .000 .

Table 3. Shapiro-Wilk Normality test

\begin{tabular}{lccc} 
& \multicolumn{3}{c}{ Shapiro-Wilk } \\
\cline { 2 - 4 } & Estat. & df & Sig. \\
\hline Compatibility with existing software & .756 & 360 & .000 \\
Ability to test the software before implementation & .764 & 360 & .000 \\
License that is distributed with the software & .873 & 360 & .000 \\
Support availability & .795 & 360 & .000 \\
IT personnel technical skills & .799 & 360 & .000 \\
Cost & .937 & 360 & .000 \\
Attitude towards use & .813 & 360 & .000 \\
\hline
\end{tabular}

Using the Shapiro-Wilk Test, the supposition of normality is not satisfied from the data recovered. The data does not distribute normally, because each value for $p$ found in each variable was less than .05 .

Table 4. Communalities in the factorial matrix

\begin{tabular}{lcc}
\hline & Initial & Extraction \\
\hline Compatibility with existing software & 1.000 & .525 \\
Ability to test the software before implementation & 1.000 & .586 \\
License that is distributed with the software & 1.000 & .462 \\
Support availability & 1.000 & .653 \\
IT personnel technical skills & 1.000 & .598 \\
Training costs for users & 1.000 & .659 \\
Training costs for support staff & 1.000 & .724 \\
\hline
\end{tabular}




\begin{tabular}{lll}
\hline Installation costs & 1.000 & .621 \\
Integration costs and customization & 1.000 & .659 \\
Costs of support services and consultancy & 1.000 & .605 \\
Entail savings in hardware costs & 1.000 & .290 \\
Lower costs in the licenses or no cost compared with proprietary licenses & 1.000 & .491 \\
The use of open source software at work would be good & 1.000 & .717 \\
The use of open source software at work would be wise & 1.000 & .699 \\
The use of open source software at work would be favorable & 1.000 & .782 \\
The use of open source software at work would be beneficial & 1.000 & .810 \\
The use of open source software at work would be positive & 1.000 & .722 \\
\hline
\end{tabular}

Commonalities were analyzed, which indicate the proportion of the variance for each variable within the main components. The results of this analysis that appear in the initial column are one, which suggests that the variable was completely explained for the common factors that appear in the factorial matrix.

Table 5. Total Variance Explained from the factorial matrix

\begin{tabular}{|c|c|c|c|c|c|c|c|c|c|}
\hline \multirow[t]{2}{*}{$\begin{array}{l}\text { Co } \\
\text { mp. }\end{array}$} & \multicolumn{3}{|c|}{ Initial Eigenvalues } & \multicolumn{3}{|c|}{$\begin{array}{c}\text { Extraction Sums of Squared } \\
\text { Loadings }\end{array}$} & \multicolumn{3}{|c|}{$\begin{array}{c}\text { Rotation Sums of Squared } \\
\text { Loadings }\end{array}$} \\
\hline & Total & $\begin{array}{l}\text { \% de } \\
\text { Variance }\end{array}$ & $\begin{array}{c}\text { Cumulative } \\
\%\end{array}$ & Total & $\begin{array}{l}\text { \% of } \\
\text { Variance }\end{array}$ & $\begin{array}{c}\text { Cumulative } \\
\%\end{array}$ & Total & $\begin{array}{l}\text { \% of } \\
\text { Variance }\end{array}$ & $\begin{array}{l}\text { Cumulative } \\
\%\end{array}$ \\
\hline 1 & 6.698 & 39.401 & 39.401 & 6.698 & 39.401 & 39.401 & 4.328 & 25.458 & 25.458 \\
\hline 2 & 2.501 & 14.714 & 54.115 & 2.501 & 14.714 & 54.115 & 3.261 & 19.180 & 44.638 \\
\hline 3 & 1.403 & 8.251 & 62.366 & 1.403 & 8.251 & 62.366 & 3.014 & 17.728 & 62.366 \\
\hline 4 & .994 & 5.848 & 68.214 & & & & & & \\
\hline 5 & .690 & 4.059 & 72.273 & & & & & & \\
\hline 6 & .651 & 3.832 & 76.105 & & & & & & \\
\hline 7 & .583 & 3.432 & 79.537 & & & & & & \\
\hline 8 & .521 & 3.065 & 82.602 & & & & & & \\
\hline 9 & .506 & 2.975 & 85.577 & & & & & & \\
\hline 10 & .471 & 2.773 & 88.350 & & & & & & \\
\hline 11 & .393 & 2.314 & 90.664 & & & & & & \\
\hline 12 & .338 & 1.987 & 92.652 & & & & & & \\
\hline 13 & .310 & 1.826 & 94.477 & & & & & & \\
\hline 14 & .290 & 1.708 & 96.185 & & & & & & \\
\hline 15 & 261 & 1.536 & 97.721 & & & & & & \\
\hline 16 & .235 & 1.381 & 99.102 & & & & & & \\
\hline 17 & .153 & .898 & 100.000 & & & & & & \\
\hline
\end{tabular}

In the initial group of values, the first three components obtained a value larger than one and represented $62.35 \%$ of the total variance, which explains the variance of more than one variable. Furthermore, it indicates that the first component explains $39.4 \%$ of the total variance, the second a $14.7 \%$ and the third $8.2 \%$.

The evidence found after the application of the Spearman statistical test showed support in each of the hypotheses stated by the researcher $(p>.01)$. 
Table 6. Hypothesis Results

\begin{tabular}{|c|c|c|}
\hline \multirow{2}{*}{ Hypothesis } & \multicolumn{2}{|c|}{ Spearman } \\
\hline & rho & Sig \\
\hline $\begin{array}{l}\mathrm{H}_{1} \text { : The compatibility with existing programs will have a significant effect in the } \\
\text { adoption of open source software. }\end{array}$ & 0.386 & 0.00 \\
\hline $\begin{array}{l}\mathrm{H}_{2} \text { : The ability to test the software before implementation will have a significant } \\
\text { effect in the adoption of open source software. }\end{array}$ & 0.353 & 0.00 \\
\hline $\begin{array}{l}\mathrm{H}_{3}: \text { The license that is distributed with the software will have a significant effect in } \\
\text { the adoption of open source software. }\end{array}$ & 0.200 & 0.00 \\
\hline $\begin{array}{l}\mathrm{H}_{4}: \text { The software's support availability will have a significant effect in the } \\
\text { adoption of open source software. }\end{array}$ & 0.228 & 0.00 \\
\hline $\begin{array}{l}\mathrm{H}_{5}: \text { The IT personnel's technical skills will have a significant effect in the } \\
\text { adoption of open source software. }\end{array}$ & 0.225 & 0.00 \\
\hline $\mathrm{H}_{6}$ : Costs will have a significant effect in the adoption of open source software. & 0.321 & 0.00 \\
\hline
\end{tabular}

The evidence found after the application of the Spearman statistical test showed support in each of the hypotheses stated by the researcher $(\mathrm{p}>.01)$.

Table 7. Mann-Whitney U test: Comparison of each factor between students and faculty members

\begin{tabular}{|c|c|c|c|c|c|c|}
\hline & People & $\mathbf{N}$ & Mean & $\begin{array}{c}\text { Sum of } \\
\text { the } \\
\text { ranks } \\
\end{array}$ & $\mathbf{Z}$ & $\begin{array}{l}\text { Asymp. } \\
\text { Sig. (2- } \\
\text { tailed) } \\
\end{array}$ \\
\hline \multirow{3}{*}{$\begin{array}{l}\text { The compatibility with } \\
\text { existing programs }\end{array}$} & Student & 288 & 191.74 & 55220.5 & & \\
\hline & Faculty & 72 & 135.55 & 9759.5 & & \\
\hline & Total & 360 & & & -4.491 & .000 \\
\hline \multirow{3}{*}{$\begin{array}{l}\text { The ability to test the software } \\
\text { before implementation }\end{array}$} & Student & 288 & 187.75 & 54073 & & \\
\hline & Faculty & 72 & 151.49 & 10907 & & \\
\hline & Total & 360 & & & -2.888 & 0.004 \\
\hline \multirow{3}{*}{$\begin{array}{l}\text { The license that is distributed } \\
\text { with the software }\end{array}$} & Student & 288 & 182.35 & 52516 & & \\
\hline & Faculty & 72 & 173.11 & 12464 & & \\
\hline & Total & 360 & & & -0.7 & 0.484 \\
\hline \multirow{3}{*}{$\begin{array}{l}\text { The software's support } \\
\text { availability }\end{array}$} & Student & 288 & 187.9 & 54116 & & \\
\hline & Faculty & 72 & 150.89 & 10864 & & \\
\hline & Total & 360 & & & -2.899 & 0.004 \\
\hline \multirow{3}{*}{$\begin{array}{l}\text { The IT personnel's technical } \\
\text { skills }\end{array}$} & Student & 288 & 181.55 & 52287.5 & & \\
\hline & Faculty & 72 & 176.28 & 12692.5 & & \\
\hline & Total & 360 & & & -0.41 & 0.681 \\
\hline \multirow{3}{*}{$\begin{array}{l}\text { The costs of open source } \\
\text { software }\end{array}$} & Student & 288 & 187.03 & 53866 & & \\
\hline & Faculty & 72 & 154.36 & 11114 & & \\
\hline & Total & 360 & & & -2.388 & 0.017 \\
\hline \multirow{3}{*}{$\begin{array}{l}\text { The use of open source } \\
\text { software at work }\end{array}$} & Student & 288 & 184.95 & 53265 & & \\
\hline & Faculty & 72 & 162.71 & 11715 & & \\
\hline & Total & 360 & & & -1.657 & 0.098 \\
\hline
\end{tabular}


The Mann-Whitney $U$ test showed a significant difference in the compatibility with the existing applications $(\mathrm{p}>.01)$, the ability to test the software before implementation $(\mathrm{p}>.05)$, the support availability for the software $(\mathrm{p}>.01)$, the costs of the open source technology $(\mathrm{p}>.05)$ and the use of open source technologies in the workplace $(\mathrm{p}>.10)$ between students and faculty members.

Table 8. The Mann-Whitney $U$ test showed a significant difference in the costs of the open source technologies $(\mathrm{p}>.05)$ between institutions with high and low budgets.

\begin{tabular}{|c|c|c|c|c|c|c|}
\hline & $\begin{array}{l}\text { Institutions } \\
\text { Academic }\end{array}$ & $\mathbf{N}$ & Mean & $\begin{array}{c}\text { Sum of } \\
\text { the ranks }\end{array}$ & $\mathbf{z}$ & $\begin{array}{l}\text { Asymp. } \\
\text { Sig. (2- } \\
\text { tailed) }\end{array}$ \\
\hline \multirow{3}{*}{$\begin{array}{l}\text { The compatibility with } \\
\text { existing programs }\end{array}$} & high budget & 294 & 182.95 & 53787.50 & & \\
\hline & low bu & 66 & 169.58 & 11192.50 & & \\
\hline & total & 360 & & & -1.034 & .301 \\
\hline \multirow{3}{*}{$\begin{array}{l}\text { The ability to test the } \\
\text { software before } \\
\text { implementation }\end{array}$} & high budget & 294 & 182.71 & 53717.50 & & \\
\hline & low budget & 66 & 170.64 & 11262.50 & & \\
\hline & total & 360 & & & -.930 & .353 \\
\hline \multirow{3}{*}{$\begin{array}{l}\text { The license that is distributed } \\
\text { with the software }\end{array}$} & high budget & 294 & 182.17 & 53557.00 & & \\
\hline & low budget & 66 & 173.08 & 11423.00 & & \\
\hline & total & 360 & & & -.667 & .505 \\
\hline \multirow{3}{*}{$\begin{array}{l}\text { The software's support } \\
\text { availability }\end{array}$} & high budget & 294 & 182.22 & 53573.00 & & \\
\hline & low budget & 66 & 172.83 & 11407.00 & & \\
\hline & total & 360 & & & -.711 & .477 \\
\hline \multirow{3}{*}{$\begin{array}{l}\text { The IT personnel's technical } \\
\text { skills }\end{array}$} & high budget & 294 & 177.65 & 52230.50 & & \\
\hline & low budget & 66 & 193.17 & 12749.50 & & \\
\hline & total & 360 & & & -1.169 & .242 \\
\hline \multirow{3}{*}{$\begin{array}{l}\text { The costs of open source } \\
\text { software }\end{array}$} & high budget & 294 & 186.28 & 54766.50 & & \\
\hline & low budget & 66 & 154.75 & 10213.50 & & \\
\hline & total & 360 & & & -2.229 & .026 \\
\hline \multirow{3}{*}{$\begin{array}{l}\text { The use of open source } \\
\text { software at work }\end{array}$} & high budget & 294 & 180.76 & 53144.50 & & \\
\hline & low budget & 66 & 179.33 & 11835.50 & & \\
\hline & total & 360 & & & -.104 & .917 \\
\hline
\end{tabular}

Table 9. Results

\section{Hypothesis}

Results

$\mathbf{H}_{1}$ : The compatibility with existing programs will have a significant effect in the adoption of open source software.

$\mathbf{H}_{2}$ : The ability to test the software before implementation will have a significant effect in the adoption of open source software.

$\mathbf{H}_{3}$ : The license that is distributed with the software will have a significant effect in the adoption of open source software.

$\mathbf{H}_{4}$ : The software's support availability will have a significant effect in the adoption of open source software.

Supported

$\mathbf{H}_{5}$ : The personnel's technical skills will have a significant effect in the adoption of open source software.

$\mathbf{H}_{6}$ : Costs will have a significant effect in the adoption of open source software.

Supported

Supported

Supported

Supported

Supported 


\section{CONCLUSIONS}

The four institutions under this study showed a higher use of open source software in applications such as Moodle (57\%), Open Office (13\%) and Linux (13\%). There was also a significant difference between the students and the faculty members in 5 of the 7 factors under scrutiny. These were the compatibility with existing technologies, the ability to test the software before implementation, the availability of support for the software, the costs of the open source software and the use of open source software in the workplace. Nevertheless, when we compared the seven factors between institutions with higher and lower budgets, we found a significant difference in the factor cost for the use of OSS. Therefore, cost is a significant factor to take into account in the possible adoption of an open source technology.

The compatibility with the existing applications, the ability to test the technology before implementation, the license that is distributed with the software, the availability of support for the software, the skills by the IT personnel and cost were the factors that had a significant effect towards the adoption of open source software. Positive attitudes towards technology may guide people to show more interest in adopting new technology, have better disposition to learn and face the challenges that may arise [4].

\section{REFERENCES}

1. Abel, R. (2006). Best practices in open source in higher education study: The state of open source software. Alliance for Higher Education Competitiveness, Inc. [online]. Retrieved from http://www.methodist.edu/csc/ossresearch/applications_vendors/OSS\%20Report.pdf

2. Ayala, C., Cruzes, D., Hauge, O., \& Conradi, R. (2011). Five Facts on the Adoption of Open Source Software. IEEE Software, 28(2), 95-99. Retrieved from ProQuest Computing.

3. Bach, P. \& Terry, M. (2010). The future of FLOSS in CHI research and practice. In CHI EA '10. Proceedings of the 28th of the international conference extended abstracts on Human factors in computing systems (pp.44734476). New York, NY: ACM. doi:10.1145/1753846.1754177

4. Blank, G. (2011, November 30). Do attitudes toward technology influence Internet use?. Retrieved from http://microsites.oii.ox.ac.uk/oxis/blog/2011/do-attitudes-toward-technology-influence-internet-use

5. Campus Computing Project (2010). Still doing more with less: Community colleges continue to confront rising enrollments and eroding budgets. Retrieved from http://www.campuscomputing.net/winter-2010-surveycommunity-college-presidents

6. Codina, L. \& Rovira, C. (2008). OpenOffice y el formato OpenDocument: funciones y compatibilidad. El Profesional de la Información, 17(4), 453-460. Retrieved from http://hdl.handle.net/10760/14299

7. Coppola, C. \& Neeley, E. (2004). Open source, open learning. Why open source makes sense for education. The Catalyst, 33(3), 13-16.

8. Davis, F. D. (1989). Perceived usefulness, perceived ease of use, and user acceptance of information. MIS Quarterly, 13(3), 319.

9. Davis, F.D. (1993). User acceptance of information technology: System characteristics, user perceptions and behavioral impacts. International Journal of Man-Machine Studies, 38, 475-487. doi:10.1006/imms.1993.1022.

10. Deek, F. P. \& McHugh, J. A. (2007). Open source: Technology and policy. (p. 298) Cambridge: Cambridge University Press.

11. Emol: Ciencia y Tecnología. (2007, December 14). Gobierno Holandés se cambiará a los software de código abierto. Retrieved from http://www.emol.com/noticias/tecnologia/detalle/detallenoticias.asp?idnoticia=285294

12. Erlich, Z. \& Aviv, R. (2007). Open source software: Strengths and weaknesses. In K. St. Amant \& B. Still (Eds.), Handbook of Research on Open Source Software (p. 189). Hershey, PA: Information Science Reference.

13. Fishbein, M. \& Ajzen, I. (1975). Belief, attitude, intention and behavior: An introduction to theory and research. Reading, Mass.: Addison-Wesley.

14. Gallego, M., Luna, P. and Bueno, S. (2007). User acceptance model of open source software. Computers in Human Behavior, 24(5), 2199-2216. doi:10.1016/j.chb.2007.10.006

15. Hignite, K. (2004, August). An open mind on open source. NACUBO: Business Office Magazine. Available: http://www.nacubo.org/Business_Officer_Magazine/Magazine_Archives/August_2004/An_Open_Mind_on_Op en_Source.html 
16. Hubona, G.S. \& Geitz, S. (1997). External variables, beliefs, attitudes and information technology usage behavior. In 30th Hawaii International Conference on System Sciences (HICSS) Volume 3: Information System Track-Organizational Systems and Technology, 7-10 Jan 1997, (pp.21-28). doi: 10.1109/HICSS.1997.661560

17. Itmazi, J.A. \& Megias, M.G. (2005). Survey: comparison and evaluation studies of learning content management systems. Retrieved from http://elearning.ppu.edu/jamil/Docs/MICRO.pdf

18. Koch, G. (2006, September 26). Michigan State University open source project fuels bottom-up teaching innovation. Michigan State University Today. Available: http://msutoday.msu.edu/news/2006/michigan-stateuniversity-open-source-project-fuels-bottom-up teaching-innovation/

19. Lemley, M. A. \& Shafir, Z. (2011). Who chooses open-source software? University Of Chicago Law Review, 78(1), 139-164.

20. Li, Y., Tan, C., Xu, H., \& Teo, H. (2011). "Open source software adoption: Motivations of adopters and amotivations of non-adopters". Database for Advances in Information Systems, 42(2), 76-94.

21. Lucid Imagination. (2009). Good information is hard to find: Guidelines for managers considering open source enterprise search. White Paper. Retrieved from http://www.docstoc.com/docs/53969506/Guidelines forManagers-Considering-Open-Source-Enterprise-Search

22. Maldonado, E. (2010). "The process of introducing FLOSS in the public administration: The case of Venezuela". Journal of the Association for Information Systems, 11(11), 756-786.

23. Olson, M. (2004, August). An open mind on open source. NACUBO: Business Officer Magazine. Retrieved from http://www.nacubo.org/Business_Officer_Magazine/Magazine_Archives/August_2004/ n_Open_Mind_on_Open_Source.html

24. Orantes, S. (2011, January 1). Viabilidad del "Modelo de Aceptación de la Tecnología" en las empresas mexicanas: Una aproximación a las actitudes y percepciones de los usuarios de las tecnologías de la información. Revista Digital Universitaria, 12(1), 5. Retrieved from http://www.revista.unam.mx/vol.12/num1/art08/index.html

25. Pfaffman, J. (2007). It's Time to consider open source Software. TechTrends. 51(3), 38-43. doi:10.1007/s11528-007-0040-x

26. Pfaffman, J. (2008). Transforming high school classrooms with free/open source software: It's time for an open source software revolution. The High School Journal. 91(3), 25-31. Retrieved from General OneFile.

27. Solomon, J. T. (2010). Open source software in medium size organizations: Key factors for adoption [dissertation]. Retrieved from ProQuest Dissertations and Theses.

28. St. Amant, K. \& Still, B. (2007). Handbook of research on open source software: Technological, economic, and social perspectives. Hershey, PA: Information Science Reference.

29. Uchida, S., Fukushima, S., Masakiyo, F., Nakamori, M., Honda, Y., \& Kanda, T. (2006). The computer literacy education using open office. In Proceedings of the 19th conference on software engineering education and training workshops, CSEETW'06. doi:10.1109/CSEETW.2006.19

30. Van Rooij, S. (2007). Perceptions of open source versus commercial software: Is higher education still on the fence?. Journal of Research on Technology in Education. 39(4), 433-453. Retrieved from http://www.eric.ed.gov/PDFS/EJ768886.pdf

31. Van Rooij, S. W. (2007). "Open Source software in US higher education: Reality or illusion?" Education and Information Technologies. 12(4), 191-209. doi: 10.1007/s10639-007-9044-6

32. Wiley, D. (2006). Open source, openness, and higher education. Innovate. 3(1). Retrieved from http://www.innovateonline.info/index.php?view=article\&id=354 